\title{
PENYULUHAN PENCEGAHAN COVID-19 DAN PEMBUATAN HANDSANITIZER DENGAN SMK NEGERI 9 KABUPATEN TANGERANG
}

\author{
Rahmawida Putri ${ }^{1}$ \\ ${ }^{1}$ Sekolah Tinggi Farmasi Muhammadiyah Tangerang \\ rahmawidaputri0@gmail.com
}

\begin{abstract}
Abstrak
Kesehatan merupakan faktor yang sangat penting dalam suatu kehidupan. Menjaga kesehatan dapat dimulai dari tangan. Tangan dapat tercegah dari infeksi bakteri dan mikroorganisme melalui program cuci tangan pakai sabun ataupun dengan menggunakan handsanitizer. Hal ini disebabkan tangan merupakan salah satu penyebab infeksi dapat masuk ke dalam tubuh. Salah satu infeksi mikroorganisme yang menyerang kesehatan saat ini adalah corona virus (Covid-19) yang dapat masuk melalui celah tangan yang belum dibersihkan. Masyarakat harus bisa mencegah dan memutuskan mata rantai terbentuknya corona virus dengan memahami dan melaksanakan protokol kesehatan yang dianjurkan. Anjuran pemerintah untuk selalu menjaga kesehatan dengan sering mencuci tangan dengan menggunakan handsanitizer, menyebabkan ketersediaan produk tersebut menjadi sangat dibutuhkan. Pembelian dalam jumlah besar merupakan salah satu penyebab ketersediaan produk menurun dan harganya sangat mahal. Sehingga masyarakat diharapkan dapat kreatif dalam membuat handsanitizer yang murah. Kegiatan pengabdian dilakukan di Laboratorium Sekolah Tinggi Farmasi Muhammadiyah Tangerang berkolaborasi dengan SMK Negeri 9 Kabupaten Tangerang untuk memberikan pengetahuan kepada siswa terhadap proses pembuatan handsanitizer untuk mengatasi kelangkaan produk di pasaran dan dapat meningkatkan kreativitas siswa dalam membuat handsanitizer sendiri. Metode yang dilakukan memberikan penyuluhan mengenai pandemi Covid-19 dan memberikan pelatihan pembuatan handsanitizer kepada para siswa. Kegiatan ini diakhiri dengan memberikan produk handsanitizer dari hasil pelatihan untuk memutus mata rantai penyebaran Covid-19..
\end{abstract}

Kata Kunci : Covid-19, Handsanitizer, Penyuluhan.

\section{PENDAHULUAN}

Kesehatan merupakan aspek yang sangat penting bagi kehidupan. Dalam menjaga kesehatan, memelihara kebersihan tangan merupakan salah satu investasi untuk meningkatkan produktivitas. Dalam melakukan aktivitas sehari-hari, tangan seringkali terkontaminasi dengan mikroba, sehingga mikroba dapat masuk ke dalam tubuh dan menyebabkan berbagai penyakit melalui perantara tangan. Menurut World Health Organization (WHO) menjaga kebersihan tangan dengan rutin merupakan bentuk proteksi diri dari ancaman berbagai penyakit. Berbagai mikroba yang menempel pada tangan pada saat beraktivitas salah satunya dapat menyebabkan infeksi virus yang dapat mematikan (Parwanto, 2020). World Health Organization (WHO) mengungkapkan bahwa pada 
awal tahun 2020 sampai tahun 2021 ratusan juta orang terjangkit infeksi akibat tertular virus atau bakteri ketika menyentuh benda disekitar maupun pada saat bersentuhan dengan orang lain.

Permasalahan yang muncul pada awal tahun 2020 merupakan bencana yang sangat mengguncang dunia. Kasus pertama sekali ditemukan pada Desember 2019 di Kota Wuhan, Cina. Kasus pertama ini menyebabkan pasien mengalami pneumonia atau radang paru-paru. Kasus ini semakin mendunia saat pasien tersebut dapat menularkan penyakit yang dideritanya ke manusia lain. Handayani, dkk. 2020 menyebutkan semenjak munculnya permasalahan penyakit ini hingga menyebar ke seluruh dunia, pada tanggal 11 Februari 2020 WHO mengumumkan nama penyakit infeksi ini dengan sebutan Coronavirus Diseae (COVID-19) yang disebabkan oleh virus Severe Acute Respiratory Syndrome Coronavirus-2 (SARS-CoV-2) dan mengungkapkan keadaan ini sebagai pandemi atau epidemic global yang mengindikasikan infeksi COVID-19.

Pandemi Corona Virus menyebabkan gejala yang dilaporkan termasuk demam pada $90 \%$ kasus, kelelahan dan batu kering pada $80 \%$ kasus, dan sesak napas pada $20 \%$ kasus, dengan gangguan pernapasan pada $15 \%$ kasus. Tes darah biasanya menunjukkan jumlah sel darah putih yang rendah (leukopenia dan limfositopenia) (Sulaiman dan Supriadi, 2020). Hal ini menyebabkan masyarakat melakukan proteksi diri dengan mengonsumsi vitamin dan menjaga kebersihan diri serta lingkungan agar terhindar dari penyebaran virus corona. Penyebaran virus corona dapat dicegah dengan melakukan gerakan Cuci Tangan Pakai Sabun (CTPS) atau dengan menggunakan Handsanitizer. Kegiatan ini dapat mengurangi kontaminasi mikroba dengan kulit terutama area tangan yang sangat sering bersentuhan dengan benda di sekitar termasuk bersalaman (Sinaga, dkk. 2020 dan Larasati \& Haribowo, 2020). Selain kegiatan mencuci tangan, pemerintah juga menganjurkan untuk menggunakan masker sebagai upaya preventif terhadap penyebaran virus corona (Suhartati, dkk. 2020).

Penggunaan sabun cuci tangan dan handsanitizer yang sangat dibutuhkan oleh masyarakat dalam mengatasi penyebaran virus corona menyebabkan ketersediaan kedua barang tersebut menjadi sangat langka dan mahal. Sehingga masyarakat diharapkan dapat kreatif dalam membuat handsanitizer yang murah. Kegiatan pengabdian dilakukan di Laboratorium Sekolah Tinggi Farmasi Muhammadiyah Tangerang berkolaborasi dengan SMK Negeri 9 Kabupaten Tangerang untuk memberikan pengetahuan kepada siswa terhadap proses pembuatan handsanitizer untuk mengatasi kelangkaan produk di pasaran dan dapat meningkatkan kreativitas siswa dalam membuat handsanitizer sendiri. Metode yang dilakukan memberikan penyuluhan mengenai pandemi Covid-19 dan memberikan pelatihan pembuatan handsanitizer kepada para siswa. Pelatihan pembuatan handsanitizer dilakukan untuk meningkatkan kemampuan kreativitas siswa dalam mengolah produk handsanitizer. Kegiatan ini diakhiri dengan memberikan produk handsanitizer dari hasil pelatihan untuk memutus mata rantai penyebaran Covid-19.

\section{METODE}

Kegiatan pengabdian kepada masyarakat dilaksanakan di Laboratorium Sekolah Tinggi Farmasi Muhammadiyah Tangerang berkolaborasi dengan SMK Negeri 9 Kabupaten Tangerang. Kegiatan ini dimulai dari observasi langsung ke SMK Negeri 9 Kabupaten Tangerang dengan wawancara terhadap Kepala Sekolah SMK Negeri 9 Kabupaten Tangerang terkait permasalahan pandemi Covid-19. Dari kegiatan observasi ini diperoleh kesimpulan bahwa kebutuhan handsanitizer untuk pencegahan Covid-19 sangat diperlukan, sementara penjualan handsanitizer di pasaran semakin langka dan mahal. Dari observasi ini, perlu diadakan kegiatan pelatihan pembuatan handsanitizer bagi siswa dan guru di lingkungan sekolah untuk meminimalisir jumlah handsanitizer yang ada di pasar.

Sosialisasi kegiatan dilakukan dengan melakukan kerjasama dengan pihak Sekolah Tinggi Farmasi Muhammadiyah Tangerang, untuk proses pelaksanaan pembuatan handsanitizer dilaksanakan di Laboratorium Sekolah Tinggi Farmasi Muhammadiyah Tangerang. Dengan melampirkan tata cara dan aturan kegiatan yang dapat dilaksanakan di masa pandemi Covid-19 dengan 
menetapkan aturan menjaga jarak pada saat kegiatan, menggunakan masker dan handscoon, serta sesering mungkin membersihkan tangan dengan sabun dan air mengalir.

Waktu pelaksanaan kegiatan pengabdian ini dimulai sejak Juni 2021 sampai dengan Juli 2021. Pelaksanan kegiatan pengabdian kepada masyarakat berupa penyuluhan pencegahan Covid-19 dan pelatihan pembuatan handsanitizer melibatkan siswa dan guru pendamping. Tahapan yang dilaksanakan dalam kegiatan pengabdian ini meliputi:

(1) Pelaksanakan penyuluhan yang dilakukan di Laboratorium Sekolah Tinggi Farmasi Muhammadiyah Tangerang mengenai permasalahan pandemi Covid-19 dan dilanjutkan dengan diskusi mengenai materi Covid19. (2) Melaksanakan pelatihan pembuatan handsanitizer yang terlebih dahulu dijelaskan alat dan bahan yang akan digunakan dalam pembuatan handsanitizer, berupa alat : (1) gelas ukur $1000 \mathrm{ml}$, (2) beaker glass, (3) gelas ukur $50 \mathrm{ml}$, (4) gelas ukur $25 \mathrm{ml}$, (5) batang pengaduk, (6) boto. Selain alat juga dibutuhkan bahan berupa : (1) Etanol 96\% sebanyak $833 \mathrm{ml}$, (2) Gliserol 98\% sebanyak 14,5 $\mathrm{ml}$, (3) Hidrogen peroksida 3\% sebanyak 41,7 ml, (4) Aquades sebanyak add $1000 \mathrm{ml}$, (5) Minyak esensial lechi sebanyak 20 tetes.

Selanjutnya dijelaskan mengenai prosedur kerja dalam pembuatan handsanitizer, yakni: (1) Sebanyak $833 \mathrm{ml}$ etanol 96\% dimasukkan ke dalam gelas ukur $1000 \mathrm{ml}$, (2) Tambahkan 41,7 ml hydrogen peroksida $3 \%$ ke dalam gelas ukur berisi etanol tersebut, (3) Selanjutnya tambahkan $14,5 \mathrm{ml}$ gliserol $98 \%$ menggunakan gelas ukur $25 \mathrm{ml}$, dan dipastikan agar sisa gliserol tidak tertinggal dengan cara membilas gelas ukur dibawah air mengalir, (4) Tambahkan aquades hingga $1000 \mathrm{ml}$, lalu aduk sampai homogen, (5) Tambahkan minyak esensial lechi sebanyak 20 tetes, lalu aduk kembali sampai homogen, (6) Pindahkan campuran ke dalam botol steril

Setelah kegiatan pelatihan pembuatan handsanitizer selesai dilaksanakan, didapat hasil dari pelatihan berupa produk handsanitizer dengan standar Organisasi Kesehatan Dunia (WHO) yang dapat digunakan untuk kepentingan di sekolah maupun di luar sekolah.

\section{HASIL DAN PEMBAHASAN}

Pelaksanaan kegiatan penyuluhan Covid-19 dan pelatihan pembuatan handsanitizer kepada siswa dan guru di lingkungan SMK Negeri 9 Kabupaten Tangerang dilakukan untuk mencegah penyebaran Covid-19 di lingkungan sekolah. Pembuatan handsanitizer ini juga dilakukan untuk memberikan pengetahuan kepada siswa dan guru mengenai cara pembuatan handsanitizer, sehingga pada saat terjadi kelangkaan dan harga handsanitizer yang sangat mahal, pihak sekolah dapat memfasilitasi siswa untuk dapat kreatif membuat handsanitizer sendiri.

Penyuluhan Covid-19 memberikan pengetahuan baru kepada para siswa dan guru mengenai Covid-19 dan bagaimana penyebaran Covid-19 tersebut terjadi. Selain itu diberikan pengetahuan mengenai bagaimana mencegah penyebaran Covid-19 sehingga siswa dan guru dapat melindungi diri dan keluarganya dari paparan Covid-19.

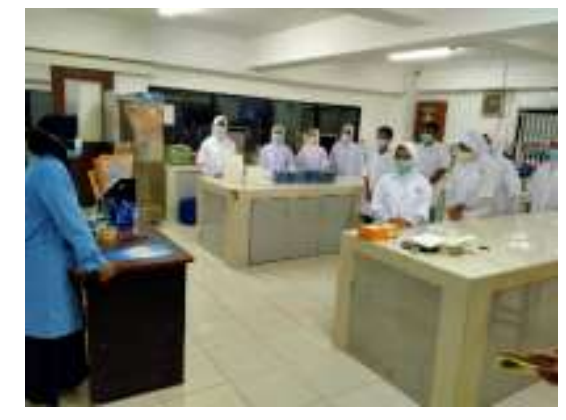

Gambar 1. Penyuluhan Tentang Covid-19

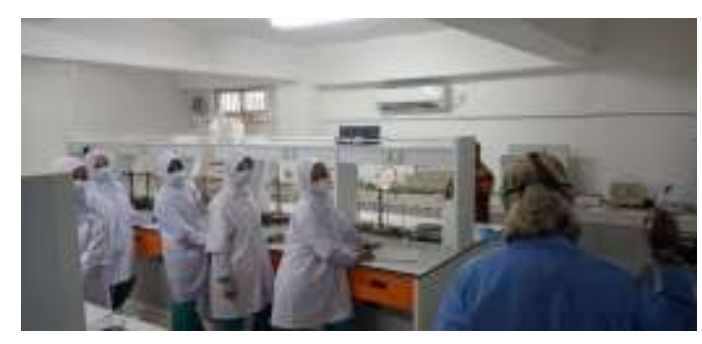

Gambar 1. Penjelasan Alat dan Bahan serta Proses Pembuatan Handsanitizer 
Pelaksanaan pelatihan pembuatan handsanitizer dilakukan mulai bulan Juni 2021 sampai dengan Juli 2021 yang bertempat di Laboratorium Sekolah Tinggi Farmasi Muhammadiyah Tangerang dengan jumlah peserta pada setiap kegiatannya sebanyak 10 hingga 15 orang siswa dengan 1 orang guru pendamping. Pelatihan ini dilakukan dengan menerapkan protokol kesehatan dengan menjaga jarak minimal 1 meter untuk setiap peserta kegiatan. Alat dan bahan yang dibutuhkan dalam kegiatan sudah dipersiapkan sebelum kegiatan berlangsung agar proses kegiatan dapat berjalan lancar. Pelaksanaan kegiatan pelatihan pembuatan handsanitizer ini juga dibantu oleh asisten laboratorium Sekolah Tinggi Farmasi Muhammadiyah Tangerang.

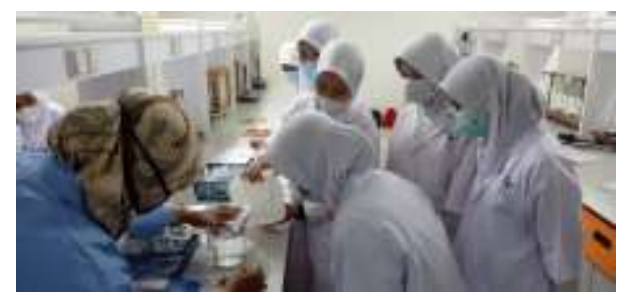

Gambar 3. Proses Pelatihan Pembuatan Handsanitizer

Dari hasil kegiatan pelatihan pembuatan handsanitizer di Laboratorium Sekolah Tinggi Farmasi Muhammadiyah Tangerang, proses kegiatannya telah berjalan dengan baik dan lancar. Hal ini dapat dilihat dari antusias para peserta dalam proses pembuatan handsanitizer dan pertanyaan yang diajukan setelah kegiatan berakhir.

Kegiatan pelatihan pembuatan handsanitizer ini menghasilkan produk sejumlah 112 botol handsanitizer berukuran $60 \mathrm{ml}$.

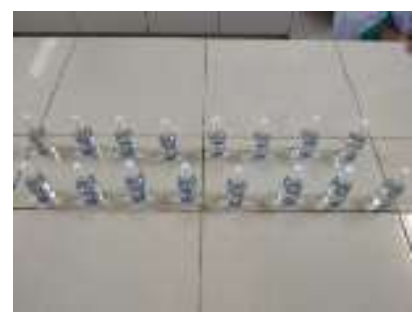

Gambar 4. Produk Hasil Pembuatan Handsanitizer
Produk handsanitizer yang telah selesai dibuat diserahkan kepada pihak SMK Negeri 9 Kabupaten Tangerang. Hal ini dilakukan untuk dapat mengurangi penyebaran Covid-19 di lingkungan sekolah SMK Negeri 9 Kabupaten Tangerang.

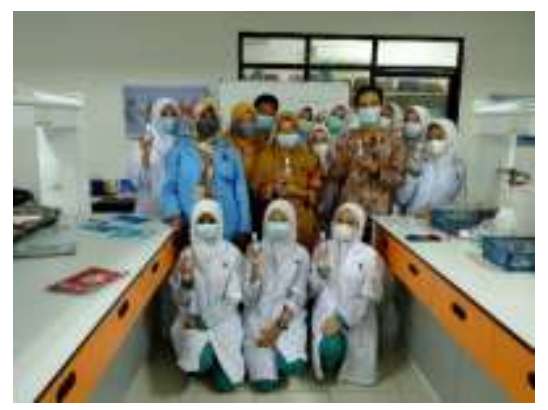

Gambar 5. Produk Handsanitizer yang diserahkan kepada siswa dan guru SMK Negeri 9 Kabupaten Tangerang

Kegiatan Pengabdian Masyarakat dengan penyuluhan pencegahan Covid 19 dan Pelatihan pembuatan handsanitizer dilakukan untuk meningkatkan kreativitas siswa dalam mengolah produk handsanitizer dalam mengatasi permasalahan pandemi Covid 19. Kegiatan ini diselenggarakan pada tanggal 17 Juni 2021, di Laboratorium Sekolah Tinggi Farmasi Muhammadiyah Tangerang yang dihadiri oleh 36 peserta siswa dan 9 guru pendamping.

Kegiatan pengabdian masyarakat diawali dengan pembukaan oleh Kepala Laboratorium Sekolah Tinggi Farmasi Muhammadiyah Tangerang. Dalam acara tersebut juga dijelaskan bahwa terdapat MoU antara Sekolah Tinggi Farmasi Muhammadiyah Tangerang dengan SMK Negeri 9 Kabupaten Tangerang yang bertujuan untuk menjalin kerjasama dalam hal penelitian, pengabdian masyarakat, dan kegiatan lain yang bertemakan pendidikan.

Kegiatan pengabdian dimulai dengan pemberian penyuluhan mengenai Covid 19 dan beberapa cara pencegahan Covid 19 salah satunya 
dengan rajin mencuci tangan dengan menggunakan sabun dan air mengalir serta menggunakan handsanitizer. Acara dilanjutkan dengan kegiatan proses pembuatan handsanitizer dengan menggunakan bahan dan alat serta prosedur kerja yang sudah ditetapkan oleh Badan Pengawas Obat dan Makanan (BPOM). Penambahan penggunaan minyak essensial dalam pembuatan produk handsanitizer untuk mengurangi bau alkohol yang cukup menyengat (Radji, 2011). Setelah kegiatan pembuatan handsanitizer berlangsung dilanjutkan dengan proses tanya jawab dan diskusi. Dari semua kegiatan yang telah berlangsung terlihat antusias siswa dan guru pendamping dalam kegiatan pengabdian masyarakat. Secara keseluruhan kegiatan pengabdian masyarakat ini berlangsung dengan baik dan berjalan lancar. Kemudian acara ini ditutup oleh Penanggungjawab kegiatan pembuatan handsanitizer.

Sanitizer merupakan cairan atau gel yang umumnya digunakan untuk mengurangi patogen pada tangan. Penggunaan sanitizer lebih efektif membunuh mikroorganisme dan lebih toleransi oleh tangan dibandingan sabun dan air (Octavia, dkk. 2021). Sediaan handsanitizer memiliki persyaratan umum, diantaranya tidak menimbulkan rasa panas pada kulit, tidak menimbulkan rasa langket pada kulit, tidak menimbulkan alergi dan aman digunakan oleh anak-anak (Munarsih, dkk. 2020, dan Kiswandono, dkk. 2020). Adapun karakteristik dari sediaan handsanitizer yakni mudah menyebar, terasa dingin selama pemakaian, tidak berminyak, tidak membuat kulit kering, memiliki sifat menghancurkan mikroba, aktif melawan fase vegetative bakteri, kapang, dan khamir.

Dari beberapa penelitian dan pengabdian yang telah dilakukan oleh peneliti Kurang, dkk pada tahun 2020 dalam pelatihan pembuatan handsanitizer mendapatkan apresiasi yang baik dari masyarakat Desa Otvai karena dapat meminimalisir pengeluaran tambahan dalam pembelian produk handsanitizer. Penelitian yang dilakukan oleh Rachmawati dan Triyana (2008) menunjukkan hasil bahwa antiseptik etanol memiliki efektivitas yang lebih baik dalam mengurangi mikroba di tangan dibandingkan dengan antiseptik lainnya.

Setelah serangkaian proses dalam pembuatan handsanitizer, para siswa dan guru pendamping dapat membawa pulang produk handsanitizer yang sudah dikemas dalam bentuk botol plastik sederhana yang sudah disterilkan. Produk handsanitizer sudah dapat digunakan setelah 3 hari dan sudah dirasakan manfaatnya setelah pemakaian. Kemasan produk yang sederhana memudahkan para siswa dan guru pendamping untuk membawa dan menggunakannya baik di dalam rumah maupun saat berada di luar rumah. Hal ini sesuai dengan luaran yang diinginkan berupa produk handsanitizer yang dapat dibuat dengan proses dan cara yang sederhana dengan biaya yang cukup terjangkau.

\section{KESIMPULAN}

Kegiatan pengabdian masyarakat dengan bermitra SMK Negeri 9 Kabupaten Tangerang berupa Penyuluhan Pencegahan Covid 19 dan Pelatihan Pembuatan Handsanitizer bagi para siswa bertujuan untuk memberikan edukasi mengenai Covid 19 dan dampaknya pada tubuh serta bagaimana cara pencegahan Covid 19 mendapat respon yang cukup baik. Produk dari handsanitizer yang telah digunakan oleh semua peserta dan didapatkan hasil bahwa tidak ada reaksi alergi yang dirasakan baik berupa iritasi maupun rasa terbakar setelah dilakukan pengamatan pasca penggunaan handsanitizer.

Berdasarkan hasil evaluasi yang telah dilakukan dari kegiatan pengabdian ini, terdapat beberapa saran yang dapat menjadi pertimbangan bagi pengabdi selanjutnya: (1) Dapat dibuat program pengembangan pelatihan pembuatan handsanitizer dengan menambahkan komposisi dari ekstrak tanaman yang bermanfaat bagi kesehatan kulit. (2) Perlu dilakukan pelatihan untuk mitra yang lebih luas sehingga dapat mencegah penyebaran Covid-19. 
UCAPAN TERIMAKASIH (Bila ada)

Ucapan terimakasih kepada Kepala Sekolah SMK Negeri 9 Kabupaten Tangerang serta para peserta. Ketua LPPM Sekolah Tinggi Farmasi Muhammadiyah Tangerang dan Laboratorium Sekolah Tinggi Farmasi Muhammadiyah yang telah bekerjasama dan berkolaborasi dalam mensukseskan kegiatan pelatihan pembuatan Handsanitizer.

\section{REFERENSI}

Handayani, D., Hadi, D. R., Isbaniah, F., Burhan, E., \& Agustin, H. (2020). Corona virus disease 2019. Jurnal Respirologi Indonesia, 40(2), 119-129.

Kiswandono, A. A., Nurhasanah, N., Nauli, P., \& Prabowo, R. (2020). Pendampingan Pembuatan Produk Handsanitizer Berbasis Alkohol Pada Kelompok Pkk Desa Fajar Baru. Prosiding Konferensi Nasional Pengabdian Kepada Masyarakat dan Corporate Social Responsibility (PKM-CSR), 3, 446-451.

Kurang, R. Y., Dollu, E. A., \& Alelang, I. F. (2020). Pelatihan Pembuatan Hand Sanitizer Dari Bahan Alami Di Desa Otvai. Jurnal Abdimas Bina Bangsa, 1(1), 137-142.

Larasati, A. L., \& Haribowo, C. (2020). Penggunaan Desinfektan dan Antiseptik Pada Pencegahan Penularan Covid-19 di Masyarakat. Majalah Farmasetika, 5(3), 137-145.

Munarsih, M., Savitri, S. I., Putren, I., Wilandari, D. F., \& Abdurohman, D. (2020). Penyuluhan Kesehatan Masyarakat melalui Skill Training Antisipasi COVID-19 dengan Busami (Pembuatan Handsanitizer Alami) Kelompok PKK di Kelurahan Sawah Ciputat. Abdi Laksana: Jurnal Pengabdian Kepada Masyarakat, 1(3), 368-373.

Octavia, D. R., Nurafifah, D., Utami, P. R., \& Pangestu, D. P. (2021). The Effect of Counseling and Training on Public Knowledge About Making
Handsanitizer from Betel Extract. Journal of Asian Multicultural Research for Medical and Health Science Study, 2(2), 8-16.

Parwanto, M. L. E. (2020). Virus Corona (2019-nCoV) Penyebab COVID-19. Jurnal Biomedika dan Kesehatan, 3(1), 1-2.

Rachmawati, F. J., \& Triyana, S. Y. (2008). Perbandingan angka kuman pada cuci tangan dengan beberapa bahan sebagai standarisasi kerja di laboratorium mikrobiologi Fakultas Kedokteran Universitas Islam Indonesia. Jurnal logika, 5(1).

Radji, M. (2011). Buku Ajar Mikrobiologi Panduan Mahasiswa Farmasi dan Kedokteran. 107, 118, 201-203, 297, Buku Kedokteran EGC, Jakarta.

Sinaga, L. R. V., Munthe, S. A., \& Bangun, H. A. (2020). Sosialisasi perilaku cuci tangan pakai sabun di desa sawo sebagai-bentuk kepedulian terhadap masyarakat ditengah mewabahnya virus covid-19. Jurnal Abdimas Mutiara, 1(2), 19-28.

Suhartati, R., Mardiana, U., \& Nurpalah, R. (2020). Pemberdayaan Masyarakat Dalam Penggunaan Hand Sanitizier dan Masker Sebagai Upaya Preventif Terhadap Covid-19. BANTENESE: JURNAL PENGABDIAN MASYARAKAT, 2(1), 2633.

Sulaeman, S., \& Supriadi, S. (2020). Peningkatan pengetahuan masyarakat desa jelantik dalam menghadapi pandemi corona virus diseases19 (covid-19). Jurnal Pengabdian UNDIKMA: Jurnal Hasil Pengabdian dan Pemberdayaan Kepada Masyarakat, 1(1).

Utomo, A. P., Primaningtyas, W. E., Ahmad, M. M., Kusminah, I. L., Andiana, R., Nindyapuspa, A., ... \& Ningrum, D. S. (2020). Pelatihan Pembuatan Hand Sanitizer dan Aplikasi Pola Hidup Bersih di SMK Negeri 4 Surabaya dalam Upaya Menyikapi Pandemi COVID-19. Educivilia: Jurnal Pengabdian pada Masyarakat, 1(2), 111-118. 
World Health Organization (WHO). (2020). Naming the coronavirus disease (COVID-19) and the virus that causes it [Internet]. Geneva: World Health Organization; 2020 [cited 2020 March 29]. Available from: https://www.who.int/emergencie s/diseases/novelcoronavirus2019/technicalguidance/namingthe-coronavirusdisease(covid2019)-and-the-virus-that-causes- 